ROCZNIKI TEOLOGICZNE

Volume 65, issue 7 - 2018

Englis h version

DOI: http://dx.doi.org/10.18290/rt.2018.65.7-7en

PIOTR KOPIEC

\title{
ECUMENICAL CRITICISM OF CAPITALISM: SELECTED APPROACHES*
}

\begin{abstract}
A bstract. The ecumenical movement stressed the need for social commitment from the very beginning. In the last decade, this has been reflected in the harsh criticism of the capitalist social order. The article discusses selected critical ecumenical interpretations of capitalism: the Accra Confession by the World Communion of Reformed Churches (2004), the economy of life programme by the World Council of Churches, and the ecumenical project of radicalizing Reformation (2014). It aims to demonstrate convergences in the theological and philosophical assumptions of the approaches discussed. It also asks the question about the similarities between the presented ecumenical reflections and the teaching of Pope Francis.
\end{abstract}

Key words: ecumenism; capitalism; crisis; Reformation; confession.

With the growth of interrelations between states and societies, the awareness of the problems and threats the world is confronted with is also increasing on a global scale. The present-day condition is usually painted in dark colors, and large numbers of sociologists, philosophers, economists, and representatives of other disciplines more and more often voice the opinion that political and economic relations must change if the world is to avoid an ecological or social cataclysm. Christian churches of various denominations take active part in this debate, and participation in it is actually the dominant feature of Pope Francis' pontificate. One can hardly fail to notice that Christians are not one bloc; what is more, socio-theological dispute is becoming

PIOTR KoPIEC, PHD, DSC-ecumenical theologian and sociologist, Assistant Professor in the Department of Protestant Theology at the Ecumenical Institute of the John Paul II Catholic University of Lublin; he is interested in Protestant theology, particularly contemporary, and in the social and cultural processes associated with the postmodern era; address for correspondence-e-mail address: petrko@kul.pl

"Publication financed as part of the "National Program for the Development of the Humanities" run by the Minister of Science and Higher Education of the Republic of Poland in the years 2016-2019. 
an increasingly strong point of intra-Christian controversy, with positions being voiced in harsh and sometimes even brutal words. The dispute is transferred to the ecumenical domain, reflecting the differences between churches in the evaluation of political and economic phenomena. Nevertheless, the largest organizations of the ecumenical movement are fairly unanimous in their criticism of the current condition of the world, thus becoming one of the sources of this criticism and at the same time an agent of change. In their opinion, what is necessary is a deep structural transformation reaching the axiological sphere-a transformation in which three fundamental dimensions are distinguished: economic justice issues, international peace issues, and gender justice issues. ${ }^{1}$ Using a few selected examples, the present article discusses the ecumenically and supra-denominationally developed approaches regarding the first of these dimensions. The article is also an attempt to show profound similarities in the cited reports of ecumenical positions as well as the similarities between the positions of ecumenical organizations and that of Pope Francis.

\section{CONTROVERSIES SURROUNDING THE CRITICISM OF THE NEOLIBERAL ECONOMIC AND SOCIAL ORDER}

One of the main controversies dividing Christians concerns the assessment of the socio-economic order that is dominant in the world. This order is usually labelled as neoliberal capitalism; additional adjectives or expressions are added to specify its nature (free market capitalism or global capitalism) or to clearly evaluate its mechanisms (such as the expression used by the Nobel Prize winner Paul Krugman, Kasino-Kapitalismus, suggesting an economic system in which the success of an enterprise is determined by luck). It must be said that the attitude towards the neoliberal economic order defines borders that go across Christian denominations, giving rise to disputes, sometimes very sharp ones, between theologians of the same denomination. Some conservative Protestant communities may be an exception in this respect. The disputes cannot be described in terms of the antinomic patterns of conservative vs. liberal or left-wing vs. right-wing, because in each case

\footnotetext{
${ }^{1}$ Christine LiEnEmann-Perrin and Wolfgang Lienemann, "Einführung," in Kirche und Öffentlichkeit in Transformationsgesellschaften, ed. Christine Lienemann-Perrin and Wolfgang Lienemann (Stuttgart: Verlag W. Kohlkammer, 2006), 12ff.
} 
these terms turn out to be incompatible, or only partly compatible, with the actual scope of the evaluations, criticisms, and ideas voiced.

In the last few years, the intensity of this controversy has been perceptively increasing. This can be attributed to numerous social facts and processes, and making an exhaustive list of these will certainly give rise to further disputes. Nevertheless, two factors are easy to identify, though they are located at different levels. The first one is the increasingly common criticism of neoliberal capitalism, formulated by various non-governmental organizations, academic and political centres, and figures influential in the social sciences, particularly intense after the financial crisis of 2008. It includes not only diagnoses concerning the global consequences of political strategies built upon neoliberal thought, but also forecasts painting the future in dark colours for particular countries in the face of changes in the sphere of work induced by technological progress. The second factor, more direct and more clearly located in theological terms, is the characteristics of Pope Francis' pontificate. Even the superficial reading Internet publications or forums, regardless of country, is enough to notice that, for many theologians and journalists, including Catholic ones, the opinions voiced by the pope are problematic, to say the least. This criticism concerns various issues addressed by Pope Francis, but one of the most frequent among them is precisely his attitude towards the current economic order, which has been so unambiguously expressed, for instance, in exhortation Evangelii Gaudium, especially in points 52-60. The emphatic words that should be mentioned include the following passage from no. 55: "One cause of this situation is found in our relationship with money, since we calmly accept its dominion over ourselves and our societies. The current financial crisis can make us overlook the fact that it originated in a profound human crisis: the denial of the primacy of the human person!" ${ }^{2}$ The subheadings dividing these points are also very revealing: "No to an economy of exclusion"; "No to the new idolatry of money"; "No to a financial system which rules rather than serves"; "No to the inequality which spawns violence." The text of the exhortation leaves no doubt that the Bishop of Rome is a strong opponent of the present economic system. It is worth adding that what is understood by "neoliberal order" in the critiques discussed below is the socio-economic model which is dominant in the world and which is based on the assumptions of the Chicago neoclassical economic school, ${ }^{3}$ reducing state interfer-

\footnotetext{
${ }^{2}$ PoPe Francis, Evangelii Gaudium, nos. 52-60.

${ }^{3}$ Manuel CaStells, Społeczeństwo sieci (Warsaw: Wydawnictwo Naukowe PWN, 2007), 140.
} 
ence in the functioning of the economy, but which is promoted (or imposed, some would say) on a global scale by some countries and supranational organizations such as the International Monetary Fund or the World Bank.

Careful observation of trends in the ecumenical movement leads to the conclusion that numerous ecumenical organizations unambiguously stress their support for Pope Francis, or even more than this - that many of the Pope's words seem to be consistent enough with those of the ecumenists to produce an impression of unisono. In fact, the ecumenical movement, or at any rate a considerable part of it, has been very strongly criticizing the socio-economic relations based on the neoliberal order for at least three decades. This stems from several processes, mainly from the associationsignificant in ecumenism - of mission with charity work; from the focus on the horizontal-i.e., earthly (hic et nunc) — dimension of building the Kingdom of God, common particularly in some Protestant churches; and, finally, from the participation of Christians from post-colonial countries in the ecumenical movement, increasing since the 1960s-for these Christians, global capitalism is simply an imposed and alien economic model replacing the nineteenth-century political colonization. ${ }^{4}$

\section{LIBERATION FOR SOCIAL JUSTICE: THE ACCRA CONFESSION (2004)}

A very important source of criticism aimed at neoliberal capitalism is the Accra Confession, a document adopted by the World Community of Reformed Churches (WCRC). This organization groups a few hundred churches that originated in the tradition of the Swiss Reformation. It was established relatively recently, in 2010, as a result of the merger of the World Alliance of Reformed Churches (WARC) and the Reformed Ecumenical Council (REC), which had been active for decades before. Although it is an organization rooted in one denominational theological tradition, the scale of its activities, its inclusive approach to cooperation with other denominations, and its very significant contribution to the activity of global ecumenical organizations make it an important actor in the ecumenical movement. It

\footnotetext{
${ }^{4}$ This was stated expressis verbis by Martin Khor, who wrote: "Globalization is what we in the Third World have for several centuries called colonization." Nayef AL-RodHAN, Definitions of Globalization: A Comprehensive Overview and a Proposed Definition (Geneva: Center for the Security Policy, 2006), 14.
} 
should be noted that the Community (before 2010, the Alliance) has always been in the vanguard of approaches that credit Christian churches with the function of actively influencing the political and economic structures to make them more just and peaceful ${ }^{5}$; it has also inspired many significant political activities undertaken in the ecumenical movement. Such attitudes are determined by the characteristic feature of Reformed theology, whose ethical dimension is focused on systematic and systemic work within the community.

The Reformed theological traditions are very strongly reflected in the Accra Confession. ${ }^{6}$ Their influence is not limited to the historical rootedness in Calvinist and Zwinglian theology but also includes inspirations present in contemporary Reformed thought. This refers, above all, to the point of departure present in this theological reflection, defined by the question: "How to find the living God today?" and, consequently, "How to recognize false gods?" The inspirations behind the Accra Confession go back to the document regarded as the foundation of the twentieth-century emancipatory Reformed tradition - namely, to the Belhar Confession, published in 1982 by the Dutch Reformed Mission Church in South Africa. In the context of apartheid, the authors of the document proclaimed: "We believe that God has revealed himself as the One who wishes to bring about justice and true peace among people." This proclamation left its clear mark in the Accra Confession, too.

The crucial assumption of this document is that economic and ecological justice do not belong exclusively to the moral or social order but are an inherent element of faith in Christ, which the integrity of the Church's mission depends on. ${ }^{8}$ Moreover, what is a common element of theological interpretations criticizing the contemporary socio-political order is that conclusions are based on the concept of Christian freedom, which, however, is not understood exclusively in spiritual and internal terms but also as liberation

\footnotetext{
${ }^{5}$ His social focus of the Community manifests itself clearly, for instance, in activities aimed at changing the nature of globalization. See: Ulrich Duchrow, Colloquium 2000. Faith Communities and Social Movements Facing Globalization (Geneva: World Council of Churches, 2002), 9.

${ }^{6}$ Nico Botha and Peter Maruping, "Reformed Christianity and the Confession of Accra: A Conversation about Unavoidable Questions in the Quest for Justice," Studia Historiae Ecclesiasticae 39, no. 1 (2013): 157-169.

${ }^{7}$ Dirk SMit, Essays in Public Theology. Collected Essays 1 (Stellenbosch: Sun Press, 2007), 52.

${ }^{8}$ The full text of the Accra Confession is included in: That All May Have Life in Fullness: World Alliance of Reformed Churches' 24th General Council Proceedings (Geneva: World Alliance of Reformed Churches, 2005), 153-160. Due to the small size of the document, no specific references are provided in its further analysis.
} 
from all kinds of social and economic oppressions. In today's context, the scale of these oppressions and their catastrophic consequences is the most fully visible in the slums of African cities, where millions of people are treated as a commodity (the document refers to this as commodification) subject to powerful economic processes.

This very strong assertion opens the first stage of the main part of reflection, identifying the signs of the times referring to the contemporary social and economic context. They show a world that drastically defies God's will, condemning billions of people to life in poverty and suffering and to death from starvation as a result of adopting an economic system that becomes its own god. The authors of the Confession very vividly illustrate this world order by citing Christ's admonition: "You cannot serve God and mammon" and stress that by allowing the contemporary humanitarian or ecological crises to happen, the world chooses its god-mammon.

According to the theologians, this mammon has a specific form: that of neoliberal economic globalization, a system that uses the basic assumptions of capitalism to justify itself. It is based on the adoption of the following theses: (1) unrestrained competition, consumerism, unlimited economic growth, and the accumulation of capital are beneficial for the whole world; (2) having private property does not involve any social obligations; (3) capital speculation, market liberalization and deregulation, privatization of public infrastructure and national resources, unlimited access for foreign investors and import, lower taxes, and unrestricted capital flow will help achieve wealth for everyone; (4) social obligations, protection of the poor and the weak, trade unions, and interpersonal relations are subject to processes of economic growth and capital accumulation. ${ }^{9}$

These specific theses are supplemented by certain observations, two of which seem to be particularly significant and have been reiterated many times by successive ecumenical organizations. Firstly, the currently dominant economic system presents itself as necessary and having no alternative (it can be added here that this is a repetition à rebours of Antonio Gramsci's idea of cultural hegemony, according to which ideas should be promoted in such a way that they seem to be consistent with common sense). Secondly, if it is dominant, then it is a contemporary form of an empire, encompassing all aspects of reality: economic, political, cultural, and military, thus defending

\footnotetext{
${ }^{9}$ World Alliance of Reformed Churches, "Covenanting for Justice in the Economy and the Earth,” Perspectives: A Journal of Reformed Thought (May 2006): 7.
} 
the interests of the group of the most powerful countries and organizations. ${ }^{10}$ It is an empire powerful enough to be able to present itself as the natural and in fact the only path to universal affluence (it is worth mentioning Fukuyama's famous assertion about "the end of history," negated on numerous occasions), which means challenging it requires a total cultural change of the system it is based on.

The second stage is the central part of the Confession-Confession "proper"; it is the largest part, too. Its form clearly resembles the Barmen Declaration of 1934, drafted by Karl Barth for the Confessing Church, proclaiming the rejection of national socialism by a group of German evangelicals. Also in this case the structure is defined by proclamations alternately beginning with "we confess" and "we reject." All these pairs stem from the already signalled assumption: if we believe in the living God, who brought justice and peace to the world, we must reject any kind of socio-economic order that puts itself over God's law and, as a result, leads to injustice and death. This kind of order is currently imposed by neoliberal global capitalism, which the document states explicitly. The economy of this system is a market economy, which means that everything becomes subject to profit calculation. Christians, by contrast, must be witnesses to the covenant that God gratuitously offered to man and that cannot be subject to the logic of the market. This covenant presents a totally different perspective, in which the foundation of economic activities is not profit but grace, encompassing all of God's creation. In this perspective, the liberal order, along with all the signs of the times that go with it, is strongly rejected not merely as deficiency but as defiance of the God's economy of life. A characteristic feature of God's economy is the primacy of man and creation over the internal economic logic - in other words, the effectiveness of economic activities is evaluated according to external criteria set by justice and peace.

As a result, the economy of life is a matter of the Christian mission. The Church must become a defender of all those who suffer due to broadly understood social exclusion and who are victims of social injustice. It must also actively promote the structures of God's economy of life and show them as an alternative order which not only is not an idealistic fantasy but is in fact a necessity in the deep crisis of humanity and the planet. Finally, the Church must pay attention to the global nature of the problems involved in the neoliberal empire paradigm.

\footnotetext{
${ }^{10}$ Ibid., 8.
} 
The last part of the Accra Confession is titled "Covenanting for Justice." It defines the programme of action that Reformed Churches are to implement, based on the economy of life. Special emphasis is placed on the need to translate this programme into the specific conditions of local communities as well as into communication between regions and communities in undertaking activities promoting the alternative socio-economic order.

As mentioned before, the Accra Confession reflected various processes that have taken place both in the ecumenical movement and in Reformed Christianity. A considerable proportion of its concepts and theological inspirations coincided in time with activities undertaken, for instance, by the World Council of Churches. It does, however, constitute a very significant source of inspiration for the theological critique of contemporary economic and political relations thanks to the coherence of its contents and thanks to its convincing wording. The significance of the Confession is evidenced by the number of references made to it in subsequent acts of opposition to the dominant order.

\section{THE ECONOMY OF LIFE PROGRAMME OF THE WORLD COUNCIL OF CHURCHES}

The Accra Confession used a dialectical model of an economy that is based on God's covenant and an economy whose foundation is the unjust system of neoliberal capitalism. The former was referred to in the capital of Ghana as the economy of life. The latter in the economy of death; this was not explicitly stated in Accra, but it was summarized many times in subsequent ecumenical documents.

This model was the conceptual axis on which the criticism of capitalism formulated by specific bodies of the World Council of Churches (WCC) is also placed. In the case of this largest ecumenical organization, the criticism of Western policy has a long tradition, dating back at least to the famous Church and Society conference, held in Geneva in 1966. It was a turning point in the activities of the ecumenical movement, mainly for two reasons: firstly, the conference placed emphasis on social commitment and the pursuit of justice and peace, which led (and continues to lead) to accusations of ideologization and politicization of the ecumenical movement ${ }^{11}$; secondly, it

\footnotetext{
${ }^{11}$ Piotr KoPIEC, Chrześcijańska alterglobalizacja. Światowa Rada Kościołów na rzecz budowy globalnego spoteczeństwa obywatelskiego (Lublin: Wydawnictwo KUL, 2016), 137ff.
} 
reflected the geographical shift in the WCC-namely, the increasing contribution of churches from postcolonial countries. But the Geneva-based organization really began to take a strongly critical stance on neoliberal capitalism when it initiated the Justice, Peace, and Integrity of Creation (JPIC) programme at the General Assembly in Vancouver in 1983. When embarking on it, the ecumenists made two main assumptions. Firstly, they asserted that the political, economic, and technological development cannot continue in the present form. Secondly, they emphasized that justice, peace, and the integrity of creation were interrelated, which meant that the pursuit of these three values had to be formulated as one coherent strategy for life. ${ }^{12}$ The programme was elaborated in detail at the meeting in Seoul in 1990, when a document called the Act of Covenanting was adopted. ${ }^{13}$ The people implementing it stressed that opposing the contemporary civilization of death and the threats it brought followed from the Christian imperative of imitating Christ as the giver of life. The threats they mentioned included the unjust economic order and the increasing income discrepancy between the rich and the poor, which leads to the poverty of billions of people vegetating in monstrously large slums surrounding African, Asian, and South American cities. In this way, though still implicitly, the programme used the dialectical model juxtaposing the economy of death and the economy of life.

This model was fully developed towards the end of the last two decades of WCC's work, starting from the General Assembly in Harare in 1998, which adopted a programme called Alternative Globalization Addressing People and Earth (AGAPE), constituting a kind of conceptual and ideological environment for the idea of the economy of life. In the capital of Zimbabwe, and subsequently during two further General Assemblies-in Porto Allegre in 2006 and in Pusan in 2013 - it was very strongly emphasized that what underlay the increasing scale of poverty, the destruction of the environment, as well as the political and social injustice that manifested themselves in many places all over the world was economic globalization, fuelled by the neoliberal philosophy of insatiable market. As a result, it was concluded that Christians had to seek new paradigms inspiring total social transformation in which economy would become a social institution and in which all dimensions of reality would not be subject to the logic of free market, as they had been before and still were. Thus, according to the theologians of Geneva,

\footnotetext{
12 Ibid., 201.

${ }^{13}$ World Convocation on Justice, Peace and the Integrity of Creation, Now is the Time. Final Document and Other Text (Geneva: World Council of Churches, 1990), 2.
} 
what is crucial is a critical reinterpretation of capitalism, particularly challenging the dogma of its "natural" character and rejecting the assumption of economic development as an autotelic value. In the adopted critical perspective, Churches must actively participate in striving for the transformation of the global socio-economic order by promoting strategies relieving the effects of crisis and presenting visions of an alternative order. The idea that theologians chose as the most appropriate for a Christian perspective, thanks to its being strongly rooted in the Bible, is precisely the "economy of life" (which was supplemented in Porto Allegre with the idea of the economy of God (oikonomia tou theou). ${ }^{14}$

The significance of the "economy of life" is accurately conveyed in a fragment of the preamble that opens the declaration presenting it:

People and the Earth are in peril due to the over-consumption of some, growing
inequalities as evidenced in the persistent poverty of many in contrast to the extrava-
gant wealth of a few, and intertwined global financial, socio-economic, ecological
and climate crises. [...] life in the global community as we know it today will come
to an end if we fail to confront the sins of egotism, callous disregard and greed
which lie at the root of these crises. [...] An Economy of Life is not only possible, it
is in the making - and God's justice lies at its very foundation! $!^{15}$

Apart from a solid theological, anthropological, and sociological basis, the economy of life also included specific economic solutions and structural proposals. They were presented many times at various meetings and in various documents, including the Bogor Declaration, titled "Economy of Life, Justice and Peace for All." Their presentation is the most coherent and exhaustive in "The São Paulo Statement: International Financial Transformation for the Economy of Life," adopted in 2012 at the global ecumenical conference devoted to the new financial and economic architecture. ${ }^{16}$ The document has two parts. The first one offers a thorough analysis of the significance of the idea of economy of life, at the same time diagnosing the causes of the deep crisis affecting the world's societies. This part mentions, among other things, the homo oeconomicus anthropology, based on the assumption that man is, by nature, an insatiable and egoistic creature; the

\footnotetext{
${ }^{14}$ World COUncil of Churches, Alternative Globalization Addressing People and Earth: A Background Document (Geneva: World Council of Churches, 2005), 6.

${ }^{15}$ Rogate Mshana and Athena Peralta, Economy of Life. Linking Poverty, Wealth and Ecology (Geneva: WCC Publications, 2010), 1.

${ }^{16}$ The São Paulo Statement. International Financial Transformation for the Economy of Life, in ibid., 99.
} 
ideology of consumerism based on this foundation, manipulating human desires and stimulating constant desires (the document even mentions the ideology of over-consumption); the economic and social order of the world, dominated by the neoliberal dogma, whose outcome is the progressing monetization and commodification of all spheres of life, leading to the reduction of values to means of exchange. The second part presents more than ten proposals related to the economic and political domains; these include regulating the financial sector, abolishing tax havens, restricting speculation activities, and providing access to banking services to the poorest. In the conclusion of the declaration, its authors formulate a very definite resolution:

We have discerned the signs of the times in the light of our calling as disciples of
Jesus. Therefore we seek to overcome capitalism, its nature and its logic and to
establish a system of global solidarity. We search for alternatives, for just, caring,
participatory and sustainable economies such as a solidarity economy and gift
economy.

The economy of life is currently the dominant approach in the work of the WCC. It is interpreted in many ways in specific regional contexts all over the planet. Its fundamental assumptions and specific systemic recommendations seem to be far beyond the actual possibilities at present, but they do create a conceptual environment for debates on Christians' participation in the shaping of the economic and social processes that determine the condition of contemporary societies.

\section{THE RADICALIZING REFORMATION PROGRAMME (2014)}

The third of the selected approaches is the youngest and the least widespread, but it is also the most radical. The direct inspiration behind its emergence was the preparations for the quincentenary of the Reformation. To the participants in the project referred to as "Radicalizing Reformation," including many ecumenists from the WCC, this celebration became an opportunity to update Luther's main theses. The Reformation is therefore interpreted anew, mainly in socio-political terms, and it should be said that certain assumptions and suggestions sound revolutionary indeed. Signatories to the project's documents include Christians from Lutheran, Reformed, Mennon-

\footnotetext{
${ }^{17}$ Ibid., 104.
} 
ite, Anglican, and Methodist Churches. It should be mentioned that the figure who played the key role in their conceptualization was Ulrich Duchrow, one of the most famous and ardent critics of capitalism in the contemporary theological debate.

It is impossible here to present all the assumptions of the German theologian's critical theory. It is, however, worth mentioning the particularly vivid comparison that he uses, juxtaposing capitalism with fascism. In his opinion, both are derived from the same root of Western civilization (Duchrow cites Galtung's statement that "Nazism is Western civilization in its extreme"18), both lead to millions of victims, both impose mechanistic ways of thinking that enforce unthinking attitudes, and both present themselves as self-justifying systems to which there is no alternative. Duchrow draws on the reflection undertaken by numerous critics of the capitalist order, pointing out a certain usurpation: the capitalist order is based on the belief that the economy is governed by the unquestionable laws of nature and that only specialists in economics can voice reliable opinions about its patterns.

The Radicalizing Reformation programme was presented in the most concise and at the same time representative way in the list of 94 theses (alluding, of course, to Luther's 95 theses), which constitute a manifesto and a summary of the project's main assumptions. In the introduction the authors assert that the world needs conversion and transformation towards more just relations, in the face of unrestrained destruction of both human and non-human life, in a world that is oppressed by the totalitarian dictatorship of money, greed, market, and exploitation. ${ }^{19}$ The document has clearly distinct sections, divided by biblical quotations as headings.

The radicalism of interpretations is visible already in the first section, in which the authors assert the need to depart from the Augustinist-Anselmian understanding of the concepts of justification and liberation in the context of the original sin and the need to relate them to specific sinful social structures causing poverty, injustice, and exclusion. In their opinion, what argues for this kind of understanding is St. Paul's theology, relating sin to the political organization of the Roman Empire. The second section consists of two parts. The first one offers a critique of capitalism by presenting the consequences

\footnotetext{
${ }^{18}$ Ulrich Duchrow, Weltwirtschaft heute - ein Feld für bekennende Kirche? (München: Kaiser Verlag, 1986), 149.

${ }^{19}$ The theses are available at: http://www.radicalizing-reformation.com/index.php/de/ (the website has two language versions; accessed: 25.01.2018). Further analysis of the project will be based on the theses posted on this website, which is why no further references are given.
} 
of "the imperial rule of money" and the destruction of social community by the paradigm of competitiveness and effectiveness. This reflection is continued in the fourth section, which contains a critical analysis of consumerist tendencies, fuelling human desires without paying attention to the costs of this for the society and for the natural environment. The second part of the second section analyses the biblically rooted economy of "enough for all" (Ökonomie des Genug), which is founded on the assumption about the dignity of the human person and which calls every Christian to understand himself or herself as God's collaborator in the formation of just, solidaritybased, and responsible social and economic structures.

The third and fifth sections analyze the interrelated issues of the need for a reinterpretation of the theology of sacrifice on the one hand and violence in society understood as a consequence of the lack of peace on the other. Although both issues are also related to the question of social exploitation, in the context of the subject under discussion these parts have smaller significance. The sixth section-the largest one-discusses the main points of Reformation theology that must be reinterpreted and updated. Two categories are crucial here: liberation and justification. Both should lead to reading the Gospel as a historic and thorough change of social relations ("There is neither Jew nor Greek..."; Gal. 3:28). They both should break free from their identifying role as markers of Protestant identity in opposition to other Christian denominations, and at the same time they must release their potential for getting societies out of the mechanisms of social injustice and exclusion.

The last, seventh part is the most radical in its form, particularly as far as its ecclesiological scenarios are concerned. The authors again invoke the basic principles of the Reformation and conclude that Christian churches must radically change the understanding of their nature and mission. What seems to be the most important is the reinterpretation-or, more accurately, in the updating - of the doctrine of universal priesthood. Whereas in Luther's times it led to the democratization of the Church, today it should be understood as a call for Christians to fight for universal civil rights and social justice. The theses are concluded with a reflection by Dietrich Bonhoeffer, who saw the Church as a small community of Christ's followers standing by those who are excluded and suffer.

Some points of the Radicalizing Reformation project may seem strikingly revolutionary. This refers both to the theological assumptions and to the social views. Nevertheless, the project is noticeable in the ongoing debate and has found itself an audience; its range of influence is shown, among other 
things, by the popularity of one of its main promoters, the already mentioned Ulrich Duchrow.

\section{CONCLUSION}

The critique of capitalism formulated inside ecumenical organizations is undoubtedly a controversial issue. Its initiators must face charges of ideologization and politicization of the ecumenical movement and Christianity in general, as well as charges of focusing on social commitment and of reducing salvation to the horizontal dimension, hic et nunc. It is nevertheless worth noting certain special circumstances in which the ecumenical criticism of the contemporary socio-economic order emerges. Firstly, its very important determinant is the growing proportion of theologians from non-Western countries, for whom capitalism is often an alien system associated with colonialism and for whom social commitment really is a matter of the Church's credibility. The criticism aimed at ecumenical organizations is therefore to some extent similar to the criticism formulated by liberation theology. Secondly, the strong wording of the approaches discussed is justified by the prospect of a real and deepening global crisis that, undoubtedly, has an axiological basis. The extent to which it is determined by neoliberal capitalism remains debatable. It is, however, certainly worth formulating a theological evaluation of the assumptions of capitalism, asking, above all, about its postulated natural character. The positions of ecumenical organizations cited above certainly contribute to this.

\section{BIBLIOGRAPHY}

Al-Rodhan, Nayef. Definitions of Globalization: A Comprehensive Overview and a Proposed Definition. Geneva: Center for the Security Policy, 2006.

Botha, Nico, and Peter Maruping. "Reformed Christianity and the Confession of Accra: A Conversation about Unavoidable Questions in the Quest for Justice." Studia Historiae Ecclesiasticae 39, no. 1 (2013): 157-169.

Castells, Manuel. Spoteczeństwo sieci [The Rise of the Network Society]. Translated by Mirosława Marody, Kamila Pawluś, and Janusz Sławiński. Warsaw: Wydawnictwo Naukowe PWN, 2007.

Duchrow, Ulrich. Colloquium 2000. Faith Communities and Social Movements Facing Globalization. Geneva: World Council of Churches, 2002.

Duchrow, Ulrich. Weltwirtschaft heute-ein Feld für bekennende Kirche? München: Kaiser Verlag, 1986. 
KOPIEC, Piotr. Chrześcijańska alterglobalizacja. Światowa Rada Kościotów na rzecz budowy globalnego spoteczeństwa obywatelskiego [Christian alterglobalization. The World Council of Churches promoting the construction of a global civil society]. Lublin: Wydawnictwo KUL, 2016.

Lienemann-Perrin, Christine, and Wolfgang Lienemann. "Einführung." In Kirche und Öffentlichkeit in Transformationsgesellschaften, edited by Christine Lienemann-Perrin, Wolfgang Lienemann. Stuttgart: Verlag W. Kohlkammer, 2006.

Mshana, Rogate R., and Athena Peralta. Economy of Life. Linking Poverty, Wealth ad Ecology. Geneva: WCC Publications, 2010.

POPE FrANCIS. Apostolic Exhortation Evangelii Gaudium, w2.vatican.va/content/francesco/en/apost _exhortations/documents/papa-francesco_esortazione-ap_20131124_evangelii-gaudium.html (accessed: 20.01.2018).

Pope Francis. Evangelii Gaudium. Cracow: Wydawnictwo M, 2013.

SMit, Dirk. Essays in Public Theology. Collected Essays 1. Stellenbosch: Sun Press, 2007.

That All May Have Life in Fullness: World Alliance of Reformed Churches. $24^{\text {th }}$ General Council Proceedings, 153-160. Geneva: World Alliance of Reformed Churches, 2005.

World Alliance of Reformed Churches. "Covenanting for Justice in the Economy and the Earth.” Perspectives. A Journal of Reformed Thought May 2006.

World Council of Churches. Alternative Globalization Addressing People and Earth: A Background Document. Geneva: World Council of Churches, 2005.

\section{Translated by Piotr Czyżewski}

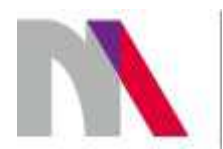

The preparation of the English version of Roczniki Teologiczne (Annals of Theology) and its publication in electronic databases was financed under contract no. 836/P-DUN/2018 from the resources of the Minister of Science and Higher Education for the popularization of science. 